\title{
KLEBSIELLA PNEUMONIAE INFECTION IN BROILER CHICKENS
}

Marwa. A.Tantawy ${ }^{1)}$, Amer, H.A. ${ }^{2)}$,El-Khyate, F. F. ${ }^{3)}$, and Moshira, A. ElAbasy ${ }^{3)}$

${ }^{1)}$ Researcher in Kafrelsheikh University. $\quad{ }^{2)}$ Department of Pathology, A.R.R.I, Giza.

${ }^{3)}$ Poultry Disease Department, Faculty of Veterinary Medicine, Kafrelsheikh University.

\section{ABSTRACT}

The epidemiology, Pathogencity and the possible ways of treatment of Klebsiella pneumoniae ( $K$. pneumoniae) infection as a respiratory pathogen in broiler chicken farms in different places in Gharbia Goernorate were investigated during 2014/2017.For this purpose 150 samples were collected from lung, trachea, liver and intestine samples of 150 diseased, 1-5-week-old commercial broiler chickens suffered from respiratory disorders, diarrhea, growth retardation and mortality with pneumonia, pericarditis, airsaculitis and enlarged liver. Bacteriological examination of swabs from trachea, lung, liver and intestine revealed Gram negative, non-motile rod-shaped organisms which were commonly isolated from lung, liver, intestine and trachea. The isolation trials revealed $10 \mathrm{~K}$. pneumoniae positive cases with an incidence (6.6\%). Identification of the isolated strains Biochemically by API $20 \mathrm{E}$ and molecularly by polymerase chain reaction (PCR) revealed that the isolates belonged to $K$. pneumoniae. The K. Pneumoniae isolate was inoculated experimentally in 7 dayold chicks and clinical signs, lesion were reproduced. Clinical signs\& P.M lesions characteristic in K.Pneumoniae infection was reproduced when the K. Pneumoniae isolates was inoculated in 7 day old chicks. K.Pneumoniae was also reisolated. Clinicopathological features and 
re-isolation of the organism from experimentally infected chicks were recorded. The results of the in vitro antibiotic sensitivity test revealed that the isolated strains were highly sensitive to gentamycin, amikacin, sulphamethoxazole-trimethoprime, ciprofloxacin and chloramphenicol, considerably sensitive to kanamycin, norfloxacin, oxytetracyclin and neomycin but resistant to Ampicillin and Erythromycin.

The clinical signs, post-mortem findings and the histopathological lesions of tissue sections from different organs of experimentally infected chickens were less severe after treatment with gentamycin, amikacin combined with sulphamethoxazole-trimethoprime in drinking water for 3 consecutive days.

\section{INTRODUCTION}

Poultry diseases is one of the most important segment of the agriculture sector in Egypt, Where investment in this industry is about 20 billion Egyptian pounds .It contributes a large part of the country's supply of animal protein (White meat and eggs). This sector has faced serious challenges through the respiratory infection.

Enterobacteriacae infection is still causing severe losses especially in young birds. Klebsiella pneumoniae is one of more than 40 genera that comprise the Enterobacteriacae family which plays as human and animal respiratory pathogen .Klebsiella infection in poultry has been recently reported to cause high mortality in balady chicks (Sarakby, 1979 and Karaman, 1980). 
Klebsiella pneumoniae infection is conveyed to the developing and very young chicks after hatching but adult birds act as a carrier (Sekariah and Seth, 1957).

The upper respiratory tract of healthy birds can harbor Klebsiella microorganism which can behave as opportunistic pathogens (Sandra and Duarte carreia 1998) K. pneumoniae can cause localized or systemic infection in poultry and other birds (Shivaprasad ,1998), celliultitis in turkey and could be associated with primary contact dermatitis and skin abrasions. (Gomis et al .,2001).

K.pneumoniae infections in growing broiler chickens did not receive much care in our country in spite of considerable importance which are found to be implicated in poultry diseases resulting in significant losses, therefore the work reported in this study was undertaken to investigate the role of $K$. pneumoniae organism in causing disease in growing broiler chickens at Gharbia Governorate, and confirming the pathogenicity by experimental infections using the isolated organism in 3 day old chicks further more studying the in vitro sensitivity test of the isolated organism against different antibiotics followed by treatment trial of experimentally infected chicks.

\section{MATERIALS AND METHODS}

\section{Collected samples:}

Specimens were collected from 150 diseased, freshly dead and sacrificed broiler chicks suffering from diarrhea and sudden death obtained from 35 farms at different localities in El-Gharbia Governorate from 2014-2017 and individual cases subjected to clinical examination. Samples were subjected to clinical, post-mortem and bacteriological

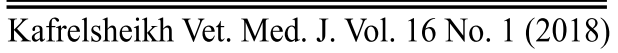


examinations. Under complete aseptic condition, loopfuls from liver, lungs, trachea and intestine were streaked on MacConkey's agar and XLD agar. The inoculated plates were incubated micro-aerobically (10\% $\mathrm{CO}_{2}$ ) at $37^{\circ} \mathrm{C}$ for $48 \mathrm{hrs}$. The suspected colonies were picked up, purified and identified morphologically and biochemically using (API 20 E Micro Test Strip Bio-Merieux, France) according to Nawaz et al., (2006) and Kamran et al., (2014). Molecular identification of $K$. pneumonia suspected colonies were carried out using PCR.

\section{Bacterial isolation:}

Field strains of $K$. pneumonia isolated from diseased broilers were used for pathogenicity test by oral, intramuscular and subcutaneous injection (Wilki et al, 2000). The $K$. pneumonia isolates were grow on MacConkey,s agar plates for $48 \mathrm{hrs}$ at $37^{\circ} \mathrm{C}$ micro-arobically. A loopful of colonies was inoculated into brain heart infusion broth for serial ten-fold dilution of the organisms. Growth was adjusted by turbidity $10^{9} \mathrm{CFU} / \mathrm{ml}$ (Tatum et al., 2012).

\section{Biochemical identification:}

The biochemical identification of the isolated strains was performed using API 20 E strip (Bio-Merieux, Lyon, France).

\section{Molecular detection (PCR):}

The molecular detection of the isolated strains was performed by using PCR and the Amplification of DNA was performed on thermal cycler (Master cycler, Eppendorf, Hamburg, Germany) according to 
Townsend et al. (1998). Primers were designed against (16S-23S rDNA) as previously described by Liu et al. (2008). Expected product size was $130 \mathrm{bp}$.

\section{Experimental infection:}

Atotal of 80, 1- day - old, White Lohman chicks, free from Klebsiella pneumoniae infection were floor reared and fed on antibioticfree ration. Feed and water were added ad libitum. Chicks were kept for one week before infection to insure that they were free from Klebsiella infection. Birds were randomly divided into 5 group.

Group (1): of 10 chicks inoculated orally with $1 \mathrm{ml}$ of sterile saline and kept as non infected non treated control group.

Group(2): of 10 chicks inoculated orally with $1 \mathrm{ml}$ sterile saline (non infected) and divided into 3 subgroups $\mathrm{A}, \mathrm{B}$, and $\mathrm{C}$ which treated with Gentamycine $0.2 \mathrm{mg} / \mathrm{chick} /$ day for consecutive days, Amikacin $15 \mathrm{mg} / \mathrm{kg} /$ day for 3 consecutive days and sulpha-Trimethoprime 10/kg/day for 10 days, respectively

Group (3): of 20 chicks were inoculated orally with $1 \mathrm{ml}$ of broth culture containing $5 \times 10^{9}$ colony forming unit per $\mathrm{ml}(\mathrm{CFU} / \mathrm{ml})$ and subdivided into 3 subgroups(A,B and (C)treated with gentamycin, Amikacin and Sulphatrimethoprim, respectively with similar doses to group (2).

Group (4): of 20 chicks were intramuscularly infected with $1 \mathrm{ml}$ broth culture contain $5 \times 109 \mathrm{CFU} / \mathrm{ml}$ and subdivided into 3 subgroups (A, B and C) and treated similar to group (3). 
Group (5): Of 20 chicks were subcutaneously infected with $1 \mathrm{ml}$ broth culture contain $5 \times 109 \mathrm{CFU}$ and divided into 3 subgroup $(A, B$ and $C)$ and treated with gentamycin, Amikacin combined with Sulphmethoprime similar to group (4)

All chickens were kept under close observation for 3 weeks during which clinical signs and mortality were recorded. Dead and sacrificed chickens were subjected to postmortem and bacteriological examinations for re-isolation of the inoculated organism.

Table (1): experimental infection

\begin{tabular}{|c|c|c|c|c|}
\hline $\begin{array}{l}\text { Group } \\
\text { codes }\end{array}$ & Infection and treatment & Breed & $\begin{array}{l}\text { NO of } \\
\text { birds }\end{array}$ & Inoculation and dose \\
\hline 1 & Non infected - non treated & \begin{tabular}{|c|} 
White \\
Lohman
\end{tabular} & 10 & $\begin{array}{l}\text { Inoculated orally with } 1 \mathrm{ml} \text { of sterial saline (Blank } \\
\text { control) }\end{array}$ \\
\hline $2 \mathrm{~A}$ & Non infected treated with Uccmagent & \begin{tabular}{|c|} 
White \\
Lohman
\end{tabular} & 3 & $\begin{array}{l}\text { Inoculated injectable with } 1 \mathrm{ml} \text { of sterial saline then give } \\
\text { Uccmagent } 0.2 \mathrm{mg} / \text { chicks once for } 3 \text { days (control -ve) } 3\end{array}$ \\
\hline 2B & Non-infected treated with Amikin & \begin{tabular}{|c|}
$\begin{array}{c}\text { White } \\
\text { Lohman }\end{array}$ \\
\end{tabular} & 3 & $\begin{array}{l}\text { Inculated injectable with } 1 \mathrm{ml} \text { of sterial saline then give } \\
\text { Amikin } 15 \mathrm{mg} / \mathrm{kg} / \text { day for } 3 \text { days (control -ve) }\end{array}$ \\
\hline $2 \mathrm{C}$ & Non - infrcted treated with Septazole & \begin{tabular}{|c|} 
White \\
Lohman
\end{tabular} & 4 & \begin{tabular}{|l} 
Iculated orally with I ml of sterile saline then give \\
Septazole $40 \mathrm{mg} / \mathrm{kg} /$ day for 10 days (control - ve)
\end{tabular} \\
\hline $3 \mathrm{~A}$ & Infected orally and treated with Uccmagent & \multirow{3}{*}{$\begin{array}{c}\text { White } \\
\text { Lohman }\end{array}$} & 6 & $\begin{array}{l}\text { Iculated orally with } 1 \mathrm{ml} \text { of } 5 \times 109 \text { after two weeks } \\
\text { divided into } 3 \text { groups and NO } 1 \text { treated with Uccmagent }\end{array}$ \\
\hline 3B & Infected orally and treated with Amikin & & 6 & NO. 2treated with Amikin and \\
\hline $3 \mathrm{C}$ & Infected orally and treated with septazole & & 8 & NO.3 treated with Septazole. \\
\hline $4 \mathrm{~A}$ & Infected I/Mand treated with Uccmangent & \multirow{3}{*}{$\begin{array}{c}\text { White } \\
\text { Lohman }\end{array}$} & 6 & \begin{tabular}{|l} 
Inculated I/M with $0.25 \mathrm{ml}$ of $5 \times 109$ after two weeks \\
divided into 3 groups and NO1 treated with Uccmagent,
\end{tabular} \\
\hline 4B & Infected I/M and treated with Amikin & & 6 & NO 2 treated with Amikin and \\
\hline $4 \mathrm{C}$ & Infected $\mathrm{I} / / \mathrm{M}$ and treated with Septazole & & 8 & NO 3 treated with Septazole. \\
\hline $5 \mathrm{~A}$ & Infected S/C and treated with Uccmagent & \multirow{3}{*}{$\begin{array}{c}\text { White } \\
\text { Lohman }\end{array}$} & 6 & $\begin{array}{l}\text { Iculated } \mathrm{S} / \mathrm{C} \text { with } 0.25 \mathrm{ml} 5 \times 109 \text { after two weeks divided } \\
\text { into } 3 \text { groups and NO1treated with Uccmagent, }\end{array}$ \\
\hline 5B & Infected S/Cand treated with Amikin & & 6 & NO 2 treated with Amikin and \\
\hline $5 \mathrm{C}$ & Infected S/C and treated with Septazole & & 8 & NO 3 treated with Septazole \\
\hline
\end{tabular}

\section{Antibiogrmme:}


The antibiotic sensitivity test of the isolates was investigated against 20 antimicrobial agents using the disc diffusion technique according to Cruick-shank et al., (1975). The test procedure was that recommended by the National Committee for Clinical Laboratory Standards (1990).

\section{Treatment trials:}

Uccmagent (Gentamycin) (Uccma-pharm) 2-4mg/kgbody weight. every 8 hours for 3 days, Amikin (each vial contain $250 \mathrm{mg}$ amikacin sulfate) (Smithklin Beecham - Pharm), 15-20 mg/kg body weight for 3 days. and Septazole suspension (Sulfamethoxazole+ Trimethoprim) (Alexandria Pharm), 4--20 mg/kg body weight were used in drinking water for 5 consecutive days for treatment of experimentally challenged chickens with K.Pneumoniae.

\section{Histopathology:}

Specimens of lung, liver and intestine were taken from experimentally infected birds fixed in $10 \%$ neutral buffered formalin, washed, dehydrated in different concentrations of alcohols, cleared in xylol and embedded in paraffin wax by routine methods. They were then Sectioned at $4 \mu \mathrm{m}$, stained with haematoxylin and eosin (HE) stain, and examined by light microscopy (Bancroft and Gamble, 2007).

\section{Statistical analysis:}

Statistical analysis of the obtained data was carried out according to Petri and Watson (1999).

\section{RESULTS AND DISCUSSION}


Ten isolates suspected to be K. Pneumoniae were isolated from 150 diseased broiler chickens with (6.6) isolation rate. Table (2).

Examined chickens suffered from respiratory disorder, septicamiemia, peritonitis, salpingitis, air sac diseases, omphalitis, artheritis, panophthalmitis and intestinal disturbances. Such diseases cause great economic losses in poultry industry not only due to high mortality rate in young bird, slow growth and poor feed conversion rates in growing birds but also due to decrease in egg production and hatchability of the infected eggs. Plesser et al., (1975); Mahalingam et al., (1988) and Rennie et al.,(1990).

The prevalence of $K$. Pneumoniae isolated from various internal organs of examined chichs was described in Table (3). The isolation rate was higher in lungs (60\%) than the liver (40\%) and the lowest rate of isolation was from the intestine (10\%). Similar results were reported by Gylstorff and Gerlach (1974) and Buxton and Fraser (1977).

K. Pneumoniae isolated from internal organs of diseased chickens on MacConkey agar, were Gram negative bacilli, non-spore forming, capsulated, non-motile and arranged singly . Colonies appear lactose fermenting, dome shaped, 3-4 $\mathrm{mm}$ diameter after overnight incubation at $37^{\circ}$ C. Fig. (1). Similar results were obtained by Mona Mohammed Aly (2014).

The biochemical activity of the recovered isolates were typed to that of K. Pneumoniae and described in Table (4). The isolates were negative in motility, Indole test was variable, Methyle red and $\mathrm{H}_{2} \mathrm{~S}$ production were negative, Vogas proskuaer, Citrate utilization, Urease 
and Sugar fermentation were positive, Similar results were reported by Kawakib Ibraheem Al Zubaid(2009).

Molecular identification by using PCR revealed that 10 isolates were positive and amplified at $130 \mathrm{bp}$ Fig. (2).similar findings were obtained by Fang et al. 2004; Ku et al. 2008 and Cheng et al. 2010). Also Yu et al. (2007).

The experimentally infected. 7-day-old broiler chickens suffered from decreased body weight gain, ruffling of the feather, progressive weakness and prostration. Respiratory symptoms appeared on the second day after infection and were manifested by gasping, abnormal breathing while intestinal troubles were represent by yellow- greenish diarrhea. The mortality rate ranged from $15-20 \%$. Table (5). Similar results were reported to Abd-Alla (1981).

The post-mortem lesions of dead and sacrificed birds revealed hyperemia of the lunge, congestion of the liver, spleen, enlargement of the gall bladder and sometimes enteritis. Fig. (2). the organisms were reisolated from lung and liver. These results were similar to that reported byAnn Moursy et al (1982) and Dessouky et al. (1982).

The results of the in vitro antibiotic sensitivity test revealed that all tested K.pneumoniae isolates were highly sensitive to gentamycin, Amikacin and Sulphamethoxazal, moderate sensitive Ciprofloxacine and Chloramphenicol and low sensitive to Noreflaxacine, Neomycin and Oxytetracycline but resistant to Cefotaxim, Amoxacillin and Cephalothin. Table (6), (7). These results were similar to that obtained by Sundaresan et al. (2007). 


\section{Treatment trials:}

The results of treatment trial of experimentally infected chicks were described in table (8). The clinical signs and post-mortum lesion were improved and mortality were disappeared in experimentally infected chicks and treated with Gentamycin 2-4 mg/kg. Body weight for three days, Amikacin 15/20 mg/kg. Body weight for three days and Sulphamethoxazol-trimethoprim $40 \mathrm{mg} / \mathrm{kg}+8 \mathrm{mg} / \mathrm{kg}$ for three days.

In this study, Klebsiella isolates showing 20\% resistance to amikacin. A low prevalence of amikacin resistance (7\%) to Klebsiella spp. isolated from meat samples were also reported by Gundogan et al. On the other hand, Ullah et al. (2009) reported that $63.04 \%$ of Klebsiella isolates were susceptible to amikacin.

Klebsiella strains recorded high antibiotic resistance with multiple antibiotic resistance (MAR). Rate of multiple antibiotic resistances was extremely high which may be due to the hazard routinely use antibiotics for treatment and control of bacterial diseases in poultry farms. When these antibiotics are administered to the birds at low levels for a long period, certain bacterial species become resistant (Kilonzo-Nthenge et al. 2007). These antibiotic-resistant bacteria can reach to human through consumption of food products from animal origin and by direct contact (Van den and Stobberingh, 2000). Our finding is in accordance with a previous literature reported by Davies et al. (2016) who reported a $25 \%$ multiple drug resistance of K. pneumoniae isolates from p psittacines. Also Bonnedahl et al. (2014) detected 13\% MDR strains from the samples they collected from ageese and free-living gulls in Alaska, USA. 
Histopathological examination of lungs of experimentally infected chickens revealed diffuse interstitial pneumoniae characterized by infiltration of monocular cells and hyperplastic bronchial epithelium Fig. (a), the liver of experimentally infected chickens showed vacuolar degeneration and sporadic necrotized hepatocytes Fig. (b) and the intestine showed necrosis, destruction and infiltration of mononuclear cells in the intestinal lumen Fig.(g).

The lung of experimentally infected chicken with K. Pneumoniae and treated with Gentamycin showed few areas with mild interstitial pneumonia and congestion of the large blood vessels. Fig. (d). The liver of experimentally Infected chicken with K. Pneumoniae and treated with Amikacin showed necrotic foci and mild mononuclear cell infiltration in the parenchyma Fig. (h). Similar results were obtained by Eman (1998).

The treatment improved the infected cases by different degrees, the best results obtained by gentamicin in which all organs seemed to be normal followed by Amikacin and sulphamethoxazol which leave mild effect on tissues on infected birds neither clinically nor histopathologically.

Table (2): Results of Klebsiella Pneuonmiae isolation

\begin{tabular}{|c|c|c|c|c|}
\hline \multirow{2}{*}{$\begin{array}{c}\text { Total No. of chicks } \\
\text { samples }\end{array}$} & \multicolumn{2}{|c|}{ Klebsiella infection } & \multicolumn{2}{|c|}{ Non klebsiella infection } \\
\hline & No. & $\%$ & No. & $\%$ \\
\hline 150 & 10 & 6.6 & 140 & 93 \\
\hline
\end{tabular}


Table (3): Prevalence of Klebsiella Pneuonmiae isolation in various organs of the examined chicks

\begin{tabular}{|c||c||c||c||}
\hline Organs & Total NO. of examined & NO. of the isolates & $\begin{array}{c}\text { Precentage of the } \\
\text { isolation (\%) }\end{array}$ \\
\hline \hline Lungs & 150 & 6 & $4 \%$ \\
\hline Livers & 150 & 3 & $2 \%$ \\
\hline Intestine & 150 & 2 & $1.3 \%$ \\
\hline
\end{tabular}

Fig. (1): Klebsiella Pneumoniae on MacConkey agar (lactose fermenter colonies).

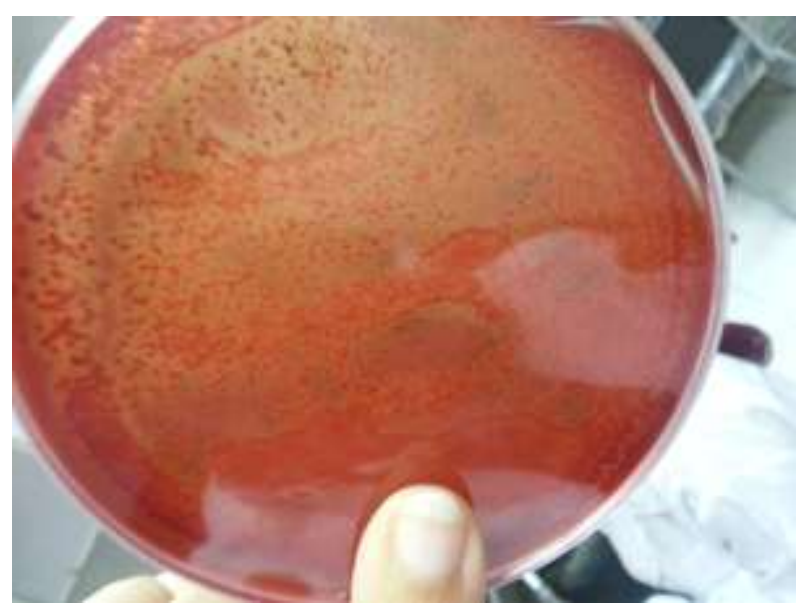

Table (4): Biochemical tests for identification of K.pneumoniae:

\begin{tabular}{||l||c||}
\hline \multicolumn{1}{|c||}{ Biochemical test } & K.pneumoniae \\
\hline \hline Motility & - \\
\hline Indole & $\mathrm{V}$ \\
\hline Methyle red & - \\
\hline VogesProskuaer & + \\
\hline Citrate utilization & + \\
\hline Urease & + \\
\hline H2S & - \\
\hline Nitrate reduction & $\mathrm{V}$ \\
\hline Gelatin liquefaction & - \\
\hline
\end{tabular}

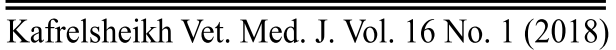


Marwa. A.Tantawy et., al.

\begin{tabular}{||l|c||}
\hline \multicolumn{1}{|c|}{ Biochemical test } & K.pneumoniae \\
\hline \hline ODC & - \\
\hline LDC & + \\
\hline Arginine dihydrolase & - \\
\hline ONPG & $\mathrm{V}$ \\
\hline Sugar fermentation & + \\
\hline Lactose & + \\
\hline Sucrose & $\mathrm{V}$ \\
\hline Dulcitol & + \\
\hline Salicin & + \\
\hline Arabinose & + \\
\hline Inositol & + \\
\hline Xylose & + \\
\hline \hline
\end{tabular}

(+): Most strain positive.

$(-)$ : Most strains negative.

(v): Some strains positive, other negative, Variable.

Fig. (2): Agarose gel electrophoresis of PCR of16S-23S rDNA "ITS" (130 bp) specific for detection andidentification of Klebsiella pneumoniae

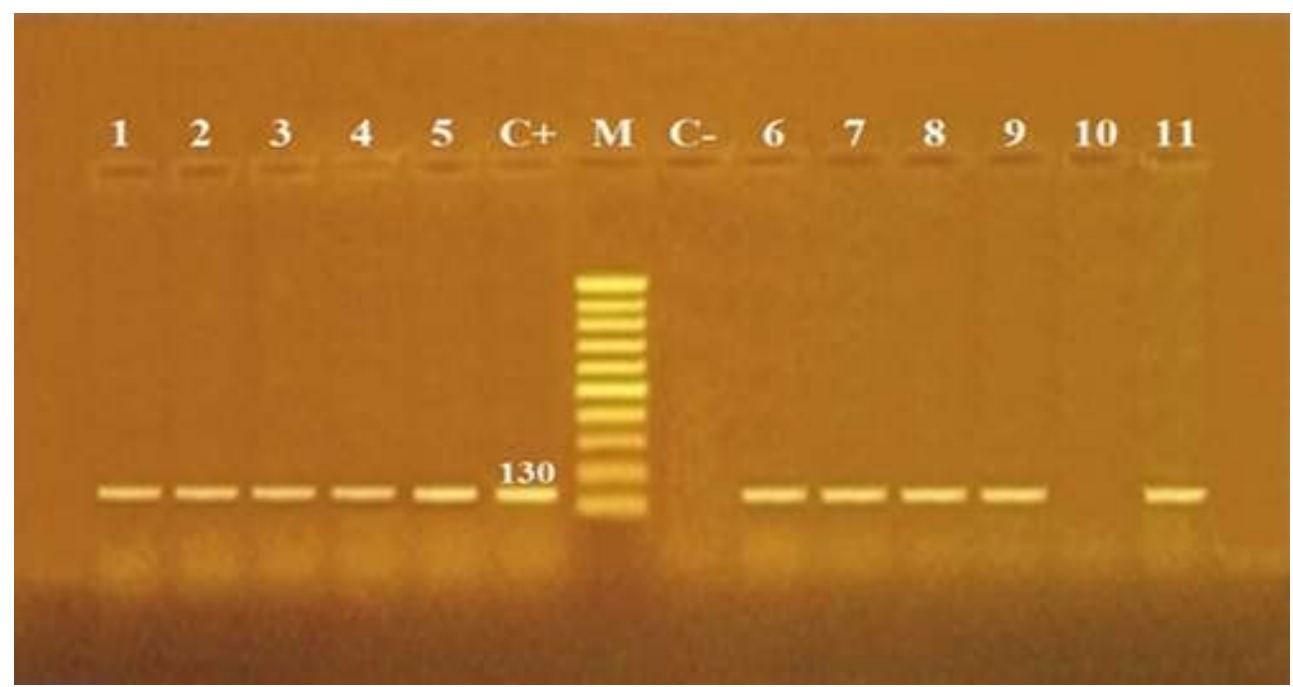

Lane M : 100bp ladder as molecular size DNA marker

Lane C+ : Control positive K. pneumoniae for16S-23S ITS.

Lane C- : Control negative.

Lanes from 1 to 9 \& 11: Positive K. pneumoniaestrains.

Lane 10 : Negative K. pneumoniaestrain.

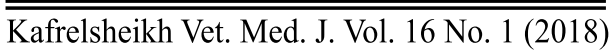


Table (5): Result of experimental infection of 7 - day - old broilers with K.pneumoniae.

\begin{tabular}{|c|c|c|c|c|c|c|c|c|c|c|c|c|c|c|}
\hline \multirow{3}{*}{$\begin{array}{c}\text { Group } \\
\text { No. }\end{array}$} & \multirow{3}{*}{$\begin{array}{c}\begin{array}{c}\text { No. of } \\
\text { infected }\end{array} \\
\text { birds }\end{array}$} & \multicolumn{11}{|c|}{ Death time } & \multirow{2}{*}{\multicolumn{2}{|c|}{ Mortality }} \\
\hline & & \multicolumn{11}{|c|}{ No. of dead chicks at different intervals post-infection/ day } & & \\
\hline & & 2 & 3 & 4 & 7 & 9 & 13 & 14 & 16 & 18 & 20 & 21 & No. & $\%$ \\
\hline 1 & 10 & 0 & 0 & 0 & 0 & 0 & 0 & 0 & 0 & 0 & 0 & 0 & 0 & 0 \\
\hline 2 & 10 & 0 & 0 & 0 & 0 & 0 & 0 & 0 & 0 & 0 & 0 & 0 & 0 & 0 \\
\hline 3 & 20 & 2 & 0 & 0 & 0 & 1 & 0 & 1 & 0 & 0 & 1 & 1 & 6 & 30 \\
\hline 4 & 20 & 2 & 2 & 1 & 1 & 0 & 1 & 1 & 0 & 1 & 1 & 2 & 12 & 60 \\
\hline 5 & 20 & 3 & 0 & 1 & 1 & 1 & 0 & 1 & 0 & 0 & 1 & 1 & 9 & 45 \\
\hline
\end{tabular}

Fig. (3): Experimentally infected chickens with K.Pneumoniae showing the clinicopathological features of the disease, diarrhea and past vent were observed in chicks and congestion of the lung

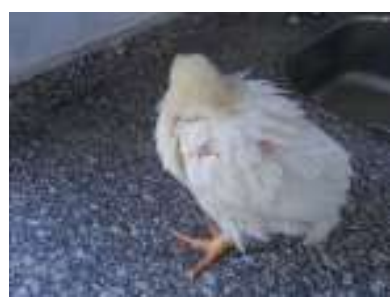

Experimental Infection showed:

A- Ruffled Feather

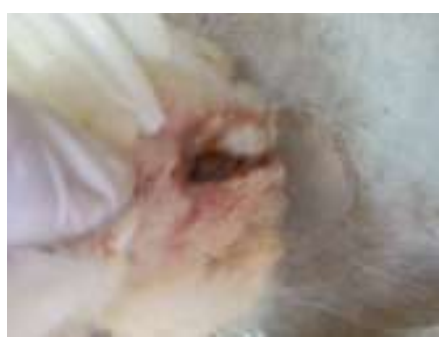

B-Pasty Diarrhea

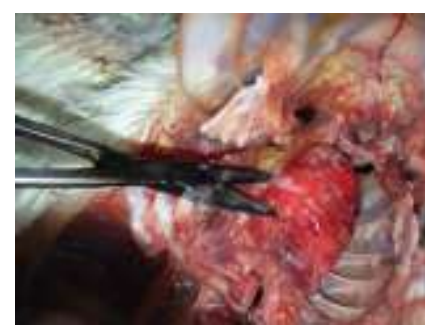

C-Hemorragic lung

Table (6): Results of in vitro antibiotic sensitivity test of $K$. pneumoniae isolates against different 20 antimicrobial agents.

\begin{tabular}{|c|c|c|c|c|c|c|}
\hline \multirow{2}{*}{ Antimicrobial agent } & \multicolumn{2}{|c|}{$\mathbf{S}$} & \multicolumn{2}{|c|}{ I } & \multicolumn{2}{|c|}{$\mathbf{R}$} \\
\hline & NO & $\%$ & No & $\%$ & NO & $\%$ \\
\hline Cephalothin $(\mathrm{CN})$ & - & - & - & - & 10 & 100 \\
\hline Amoxicillin(AMX) & - & - & 1 & 10 & 9 & 90 \\
\hline Erythromycin (E) & 1 & 10 & 2 & 20 & 7 & 70 \\
\hline
\end{tabular}

$\overline{\text { Kafrelsheikh Vet. Med. J. Vol. } 16 \text { No. } 1 \text { (2018) }}$ 


\begin{tabular}{|c|c|c|c|c|c|c|}
\hline Cefotaxim (CF) & - & - & 3 & 30 & 7 & 70 \\
\hline Ampicillin (AM) & 1 & 10 & 3 & 30 & 6 & 60 \\
\hline Oxytetracycline (T) & 2 & 20 & 2 & 20 & 6 & 60 \\
\hline Norfloxacin (NOR) & 3 & 30 & 1 & 10 & 6 & 60 \\
\hline Chloramphenicol (C) & 4 & 40 & 1 & 10 & 5 & 50 \\
\hline $\operatorname{Neomycin}(\mathbf{N})$ & 2 & 20 & 3 & 30 & 5 & 50 \\
\hline Ciprofloxacin (CP) & 5 & 50 & 1 & 10 & 4 & 40 \\
\hline Kanamycin (K) & 3 & 30 & 4 & 40 & 3 & 30 \\
\hline Sulphamethoxazol (SXT) & 6 & 60 & 1 & 10 & 3 & 30 \\
\hline Amikacin (AK) & 7 & 70 & 1 & 10 & 2 & 20 \\
\hline Gentamicin (G) & 9 & 90 & - & - & 1 & 10 \\
\hline
\end{tabular}

Table (7): Antimicrobial resistance profile of K.pneumoniae strains $(\mathrm{n}=10)$.

\begin{tabular}{|c|c|c|c|}
\hline NO & Strain & Antimicrobial resistance profile & $\begin{array}{l}\text { MAR } \\
\text { index }\end{array}$ \\
\hline 1 & K.pneumoniae & CN, AMX, E, CF, AM, T, NOR, C, N, CP, K, SXT, AK, G & 1 \\
\hline 2 & K.pneumoniae & CN, AMX, E, CF, AM, T, NOR, C, N, CP, K, SXT, AK & 0.928 \\
\hline 3 & K.pneumoniae & CN, AMX, E, CF, AM, T, NOR, C, N, CP, K, SXT & 0.857 \\
\hline 4 & K.pneumoniae & CN, AMX, E, CF, AM, T, NOR, C, N, CP & 0.714 \\
\hline 5 & K.pneumoniae & $\mathrm{CN}, \mathrm{AMX}, \mathrm{E}, \mathrm{CF}, \mathrm{AM}, \mathrm{T}, \mathrm{NOR}, \mathrm{C}, \mathrm{N}$ & 0.643 \\
\hline 6 & K.pneumoniae & CN, AMX, E, CF, AM, T, NOR & 0.500 \\
\hline 7 & K.pneumoniae & $\mathrm{CN}, \mathrm{AMX}, \mathrm{E}, \mathrm{CF}$ & 0.286 \\
\hline 8 & K.pneumoniae & $\mathbf{C N}, \mathbf{A M X}$ & 0.143 \\
\hline 9 & K.pneumoniae & CN, AMX & 0.143 \\
\hline 10 & K.pneumoniae & $\mathbf{C N}$ & 0.071 \\
\hline & & Average & \\
\hline
\end{tabular}




\begin{tabular}{llll}
\hline \hline CN: Cephalothin & AMX: Amoxicillin & E: Erythromycin & CF: Cefotaxim \\
AM: Ampicillin & T: Oxytetracycline & NOR: Norfloxacin & C: Chloramphenicol \\
N: Neomycin & CP: Ciprofloxacin & K: Kanamycin & SXT: Sulphamethoxazol \\
AK: Amikacin & G: Gentamicin & &
\end{tabular}

Table(8): Treatment trials of experimentally infected broilers with K.Pneumoniae.

\begin{tabular}{|c|c|c|c|c|c|}
\hline \multirow{2}{*}{$\begin{array}{c}\text { Group } \\
\text { No. }\end{array}$} & \multirow{2}{*}{ No. of birds } & \multirow{2}{*}{ Treatment } & \multirow{2}{*}{ Drug used } & \multicolumn{2}{|c|}{ Mortality } \\
\hline & & & & No. & $\%$ \\
\hline 1 & 10 & Non Infected + Non treated & - & 0 & 0 \\
\hline 2 & 10 & Non Infected + treated & Uccmagent+ Amikin+ Septazole & 0 & 0 \\
\hline 3 & 20 & Non Infected + treated & Uccmagent+ Amikin+ Septazole & $6 / 20$ & $30 \%$ \\
\hline 4 & 20 & Non Infected+ treated & Uccmagent+ Amikin+ Septazole & $13 / 20$ & $65 \%$ \\
\hline 5 & 20 & Infected + treated & Uccmagent+ Amikin+ Septazole & $9 / 20$ & $45 \%$ \\
\hline
\end{tabular}

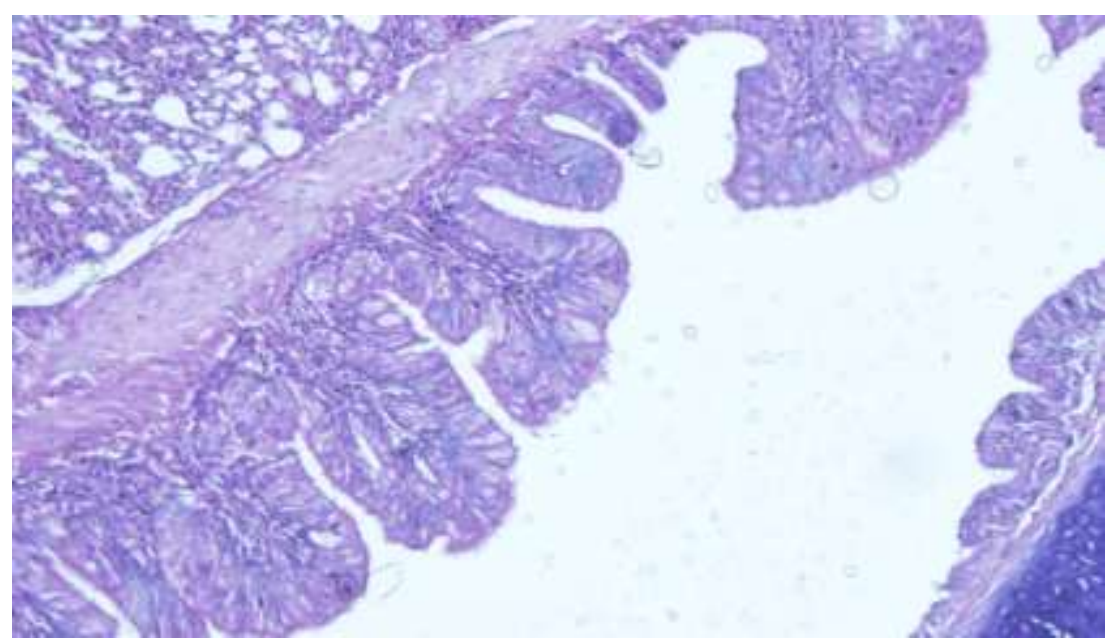

Fig. (a): Lung of a chick Infected orally with $1 \mathrm{ml}$ broth culture contain $5 \times 10^{9}$ $\mathrm{CFU} / \mathrm{ml}$. of $K$.

Pneumoniae (group3) showing hyperplastic bronchial epithelium (H\&E, X100). 


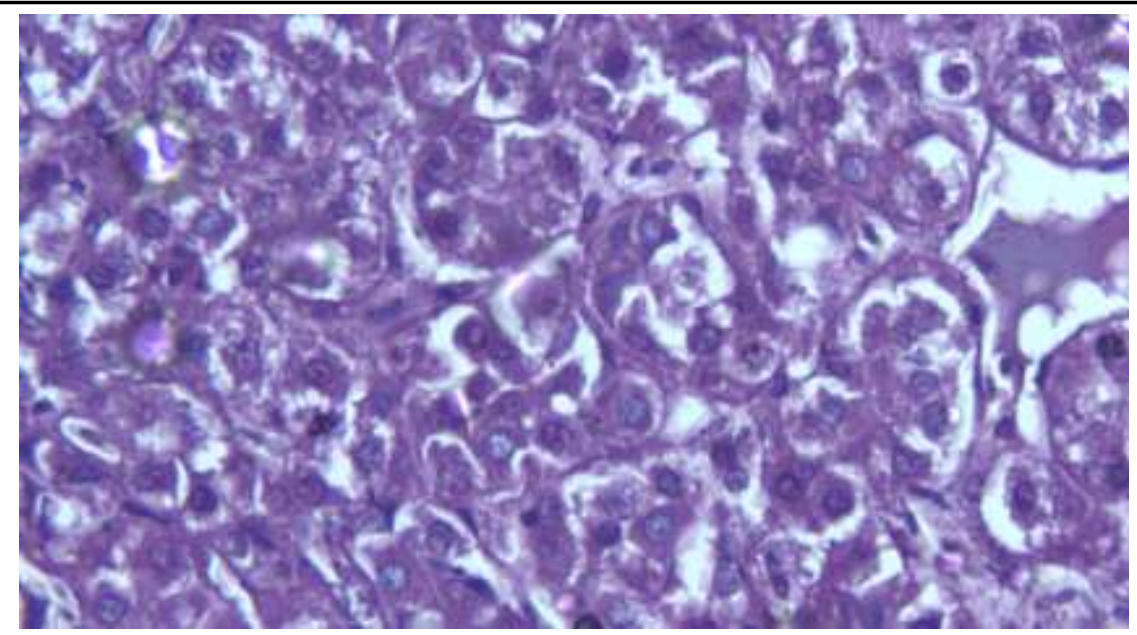

Fig. (b): Liver of a chick Infected orally with $1 \mathrm{ml}$ broth culture of $k$. Pneumoniae contained $5 \times 10^{9}$

$\mathrm{CFU} / \mathrm{ml}$. (group3) showing vacuolar degeneration and sporadic necrotized hepatocytes (H\&E, X400).

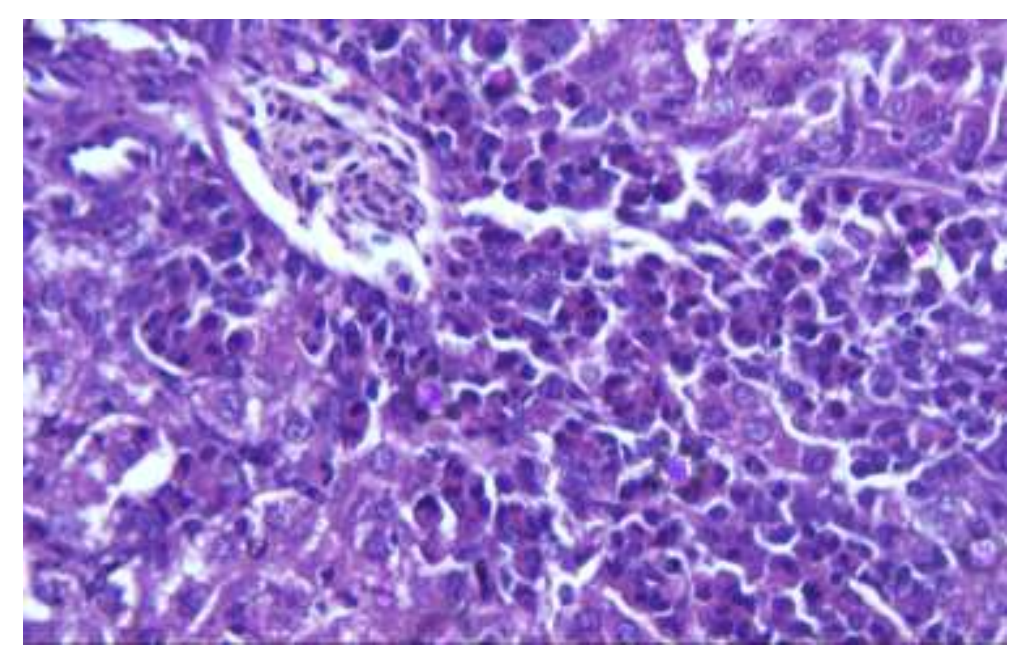

Fig. (c): Liver of a chick Infected orally with $1 \mathrm{ml}$ broth culture of $K$. Pneumoniae contained $5 \times 10^{9}$

CFU/ml. (group3) showing infiltration of monocular cells and sometimes neutrophils in the portal areas (H\&E, X400). 


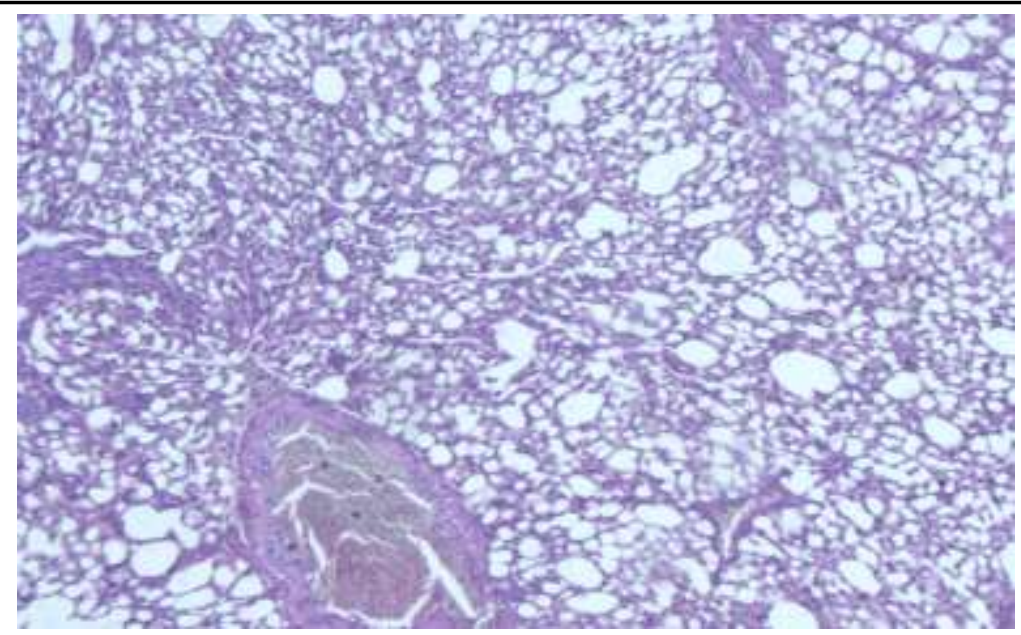

Fig. (d): Lung of a chick orally Infected with $1 \mathrm{ml}$ broth culture of $K$. Pneumoniae contained $5 \times 10^{9}$

$\mathrm{CFU} / \mathrm{ml}$. and treated with Gentamycin (group 3A) showing few areas with mild interstitial pneumonia and congestion of the large blood vessels (H\&E, X40).

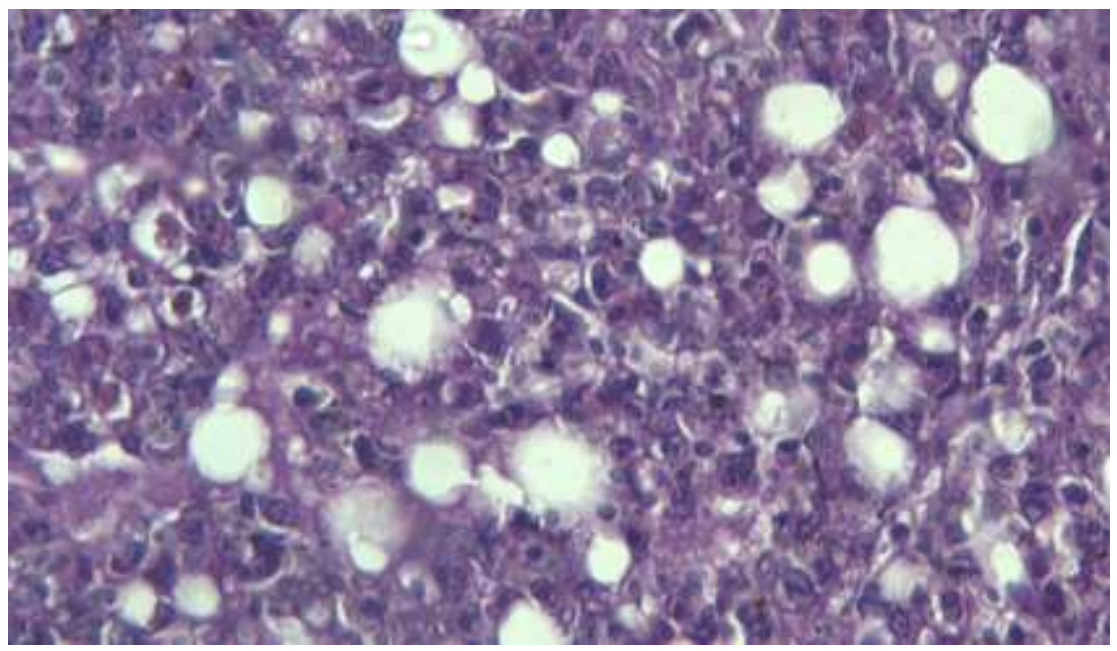

Fig. (e): Lung of a chick intramuscularly Infected with $1 \mathrm{ml}$ broth culture of $K$. Pneumoniae contained $5 \times 10^{9} \mathrm{CFU} / \mathrm{ml}$. (group 4) showing diffuse interstitial pneumoniae characterized by infiltration of monocular cells in the interstitial tissue (H\&E, X100). 


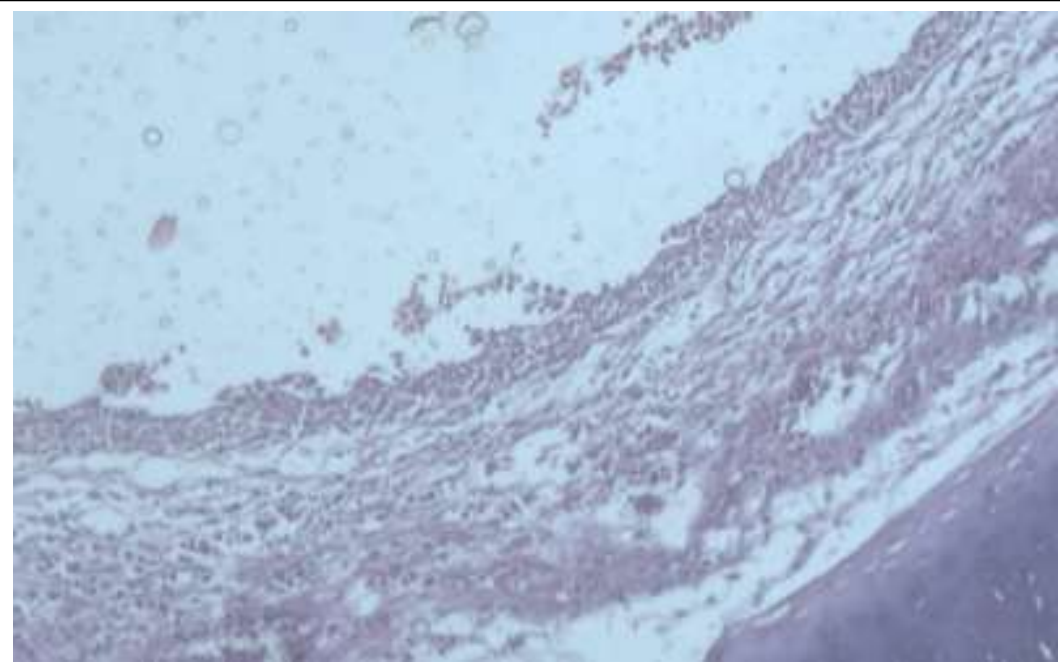

Fig. (f): Trachea of a chick infected intramuscularly with $1 \mathrm{ml}$ broth culture of K. Pneumoniae contained $5 \times 10^{9} \mathrm{CFU} / \mathrm{ml}$.(group4) showing trachitis, desquamation of tracheal epithelium with sub-epithelial edema and infiltration of mononuclear cells (H\&E, X40).

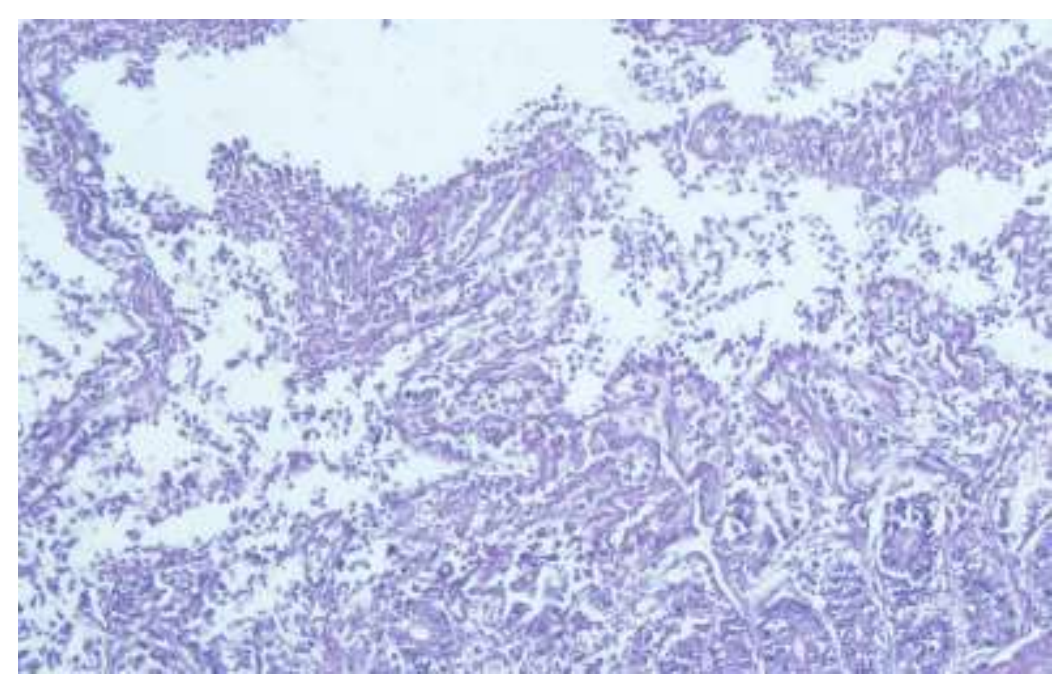

Fig. (g): Intestine of a Chick intramuscularly infected with $1 \mathrm{ml}$ broth culture of K. Pneumoniae contained $5 \times 10^{9} \mathrm{CFU} / \mathrm{ml}$. (group4) Showing necrosis, destruction and infiltration of mononuclear cells in the intestinal lumen (H\&E, X40). 


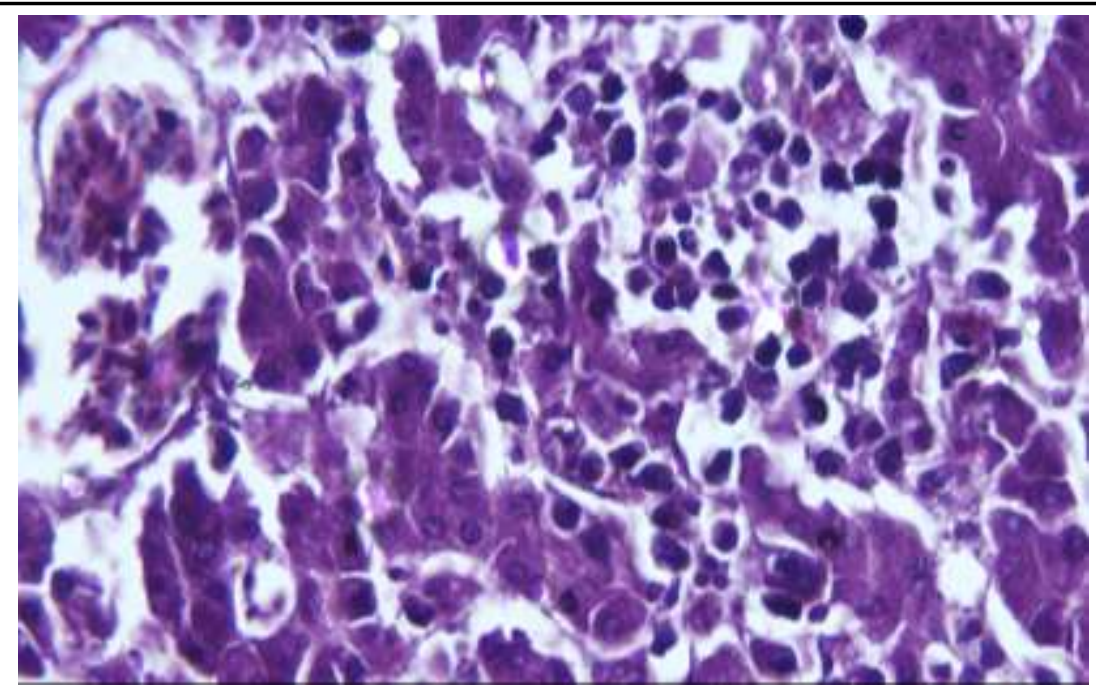

Fig. (h): Liver of a chick intramuscularly Infected with $1 \mathrm{ml}$ broth culture of $K$. Pneumoniae contained $5 \times 10^{9} \mathrm{CFU} / \mathrm{ml}$ and treated with Amikacin. (group 4B) showing necrotic foci and mononuclear cell infiltration in the parenchyma (H\&E, X400).

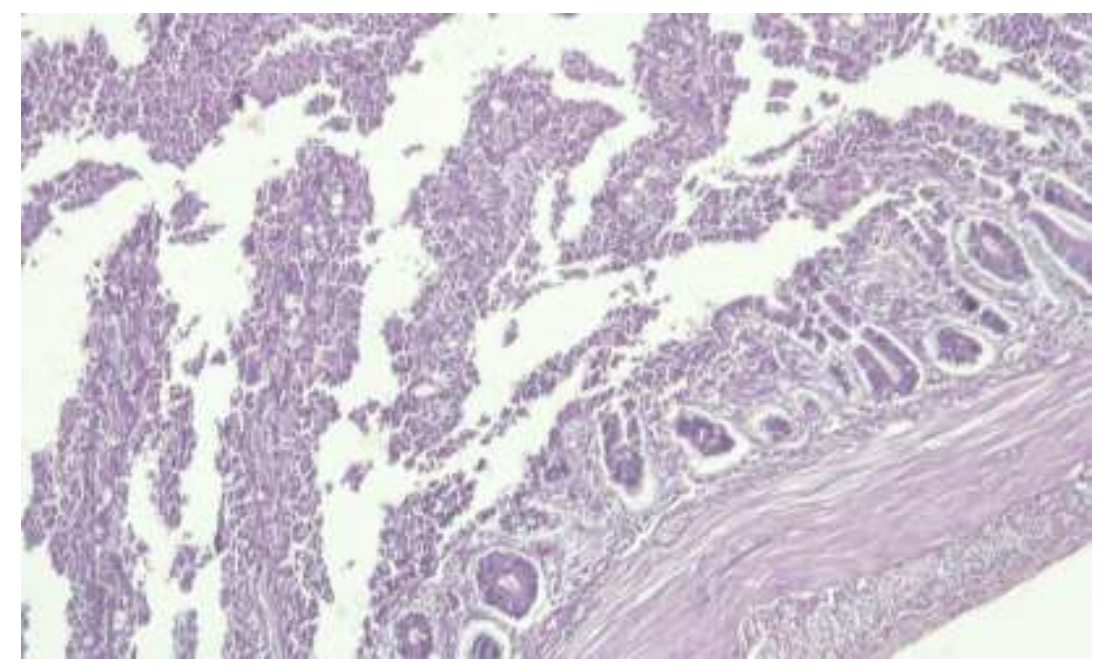

Fig. (i): Intestinal glands of a chick intramuscularly infected with $1 \mathrm{ml}$ broth culture of $K$. Pneumoniae contained $5 \times 10^{9} \mathrm{CFU} / \mathrm{ml}$ and treated with Amikacin (group 4B) showing destructed, degenerated and shrinked 
intestinal glands with mononuclear cell infiltration in the lamina propria (H\&E, X40).

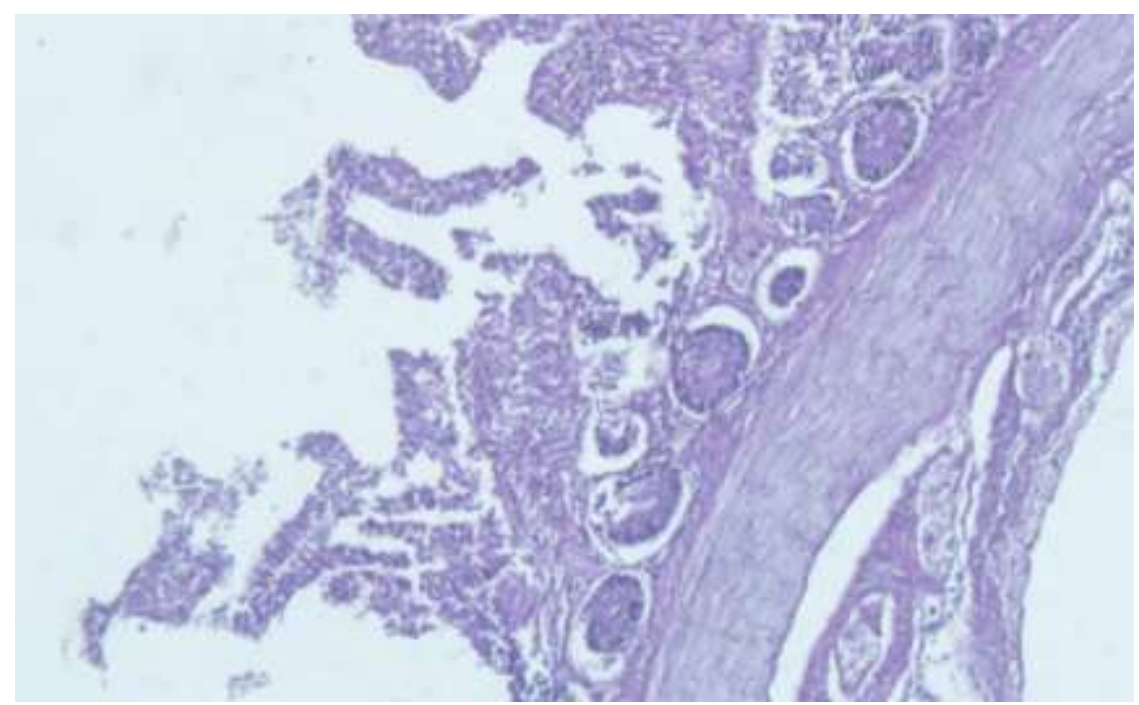

Fig. (j): Intestine of a Chick subcutaneously Infected with $1 \mathrm{ml}$ broth culture of K. Pneumoniae contained $5 \times 10^{9} \quad \mathrm{CFU} / \mathrm{ml}$ (group 5) showing necrosed, destructed and shrinked intestinal villi (H\&E, X40).

\section{CONCLUSION}

This study spotlight the prevalence and incidence of Klebsiella Pneumoniae in clinically diseased chicken suffered from respiratory manifestation. The study confirmed the pathogenic potential of the isolated strains and their association with clinical manifestations in respiratory tract infections of broiler chicken. Antimicrobial susceptibility pattern showed high multiple antibiotic resistances which require strict regulations of the use of antibiotics in veterinary therapy to minimize the emergence of resistant bacteria in chickens which may increase the public health problem.

\section{REFERENCES}

$\overline{\text { Kafrelsheikh Vet. Med. J. Vol. } 16 \text { No. } 1 \text { (2018) }}$ 
- Abd - Alla. O. A. M. (1981): Histopathological and clinic pathological studies on poultry following artificial infection by Klebsiella. M. V. Sc. Thesis, Fac. Vet. Med., Cairo Univ.

- Ann, MOurs; Zeinab, M. Niazi and Osaman, MA. (1982): Some pathological and bacteriological aspects of Klebsiella infection J.Egypt.Vet. Med. Ass., 42 (2):125-136.

- Bancroft, J. D. and Gamble, M. (2007): Theory and Practice of Histological Techniques. ${ }^{\text {th }}$ Ed. Churchill Livingstone, London, UK, pp: 125-138.

- Bonnedahl J, Hernandez, J, Stedt J, Waldenström J, Olsen B \&Drobni M (2014): Extended-Spectrum $\beta$-lactamases in Escherichia coli and Klebsiellapneumoniae in gulls, Alaska, USA.Emerging Infectious Diseases, 20, 897-899 .

- Buxton, A. and Fraser, G. (1997): Animal Microbiology, Vol. 1Blackwell Scientific Publications, Oxford.

- Cheng HY, Chen YS, Wu CY, Chang HY, Lai YC. And Peng HL (2010): rmpA regulation of capsular polysaccharide biosynthesis in Klebsiella pneumoniae CG43. J Bacteriol. 192:3144-3158.

- Cruickshank, R., Dugaid, J. P., Marmion, B. P. and Swain, R. H. (1975): Medical Microbiology, $12^{\text {th }}$ Ed, 522-35. Living stone L.T.D, Edinburgh, London, New York.

- Eman, M. Z. (1998): Microbiology and serologe on avien Klebsiellae M.V.Sc. Thesis, Fac. Vet. Med., Cairo Univ. 
- Fang CT, Chuang YP, Shun CT, Chang SC and Wang JT. (2004): A novel virulence gene in Klebsiella pneumoniae strains causing primary liver abscess and septic metastatic complications. J Exp Med. 199:697-705.

- Gomis, S. K. Amoako. M, Ngeleka, L. Belanger, B. Althouse, L, kumor, E. Waters, s. Stephens, CRiddell, A.Potter and B.Allan (2001): Histopathologic and bacteriologic evaluations of cellulitis detected in legs and caudal abdominal regions of turkeys Avian diseases 46: 192 -197.

- Gundogan N, Citak S, Yalcin E (2011): Virulence properties of extended spectrum beta-lactamase-producing Klebsiella species in meat samples. J. Food Prot. 74:559-564.

- Gylstorff, I. and Gerlach, H. (1974): Klebsiella aerogenes infection in turkey poults and therapy experiment with polymyxin B.Deut. Tierarzt. Woch., 81 (13): 298-299.

- Jeffrey, J. S., Shivaprasad, H. L., Duran, L., Cardona, C. J. and Charlton, B. R. (1993): Facial cellulitis associated with fowl cholera in commercial turkeys. Avian diseases, 1121-1129.

- Kamran, M., Ahmad, M. U. D., Anjum, A. A., Maqbool, A., Muhammad, K., Nawaz, M., and Ali, M. A. (2014): Studies on the antibiotic sensitivity pattern of isolates of $P$. multocida from baffaloes JAPS, Journal of Animal and Plant Sciences, 24: 1565-1568. 
- Karaman, R. (1980): Studies on some bacterial diseases of poultry casusing high mortality in balady hateries (in Monofia Province).M.v.Sc., thesis Fac. Vet Med .Cairo Univ.

- Kawakib Ibraheem AL Zubaidi (Thi-Qar University -College of Science) (2009): Identification of the most bacterial isolates from the bile of broiler Chicks by API 20E system.

- Kilonzo-Nthenge, S. N. Nahashon, 1 F. Chen, and N. Adefope, (2007): Prevalence and Antimicrobial Resistance of Pathogenic Bacteria in chicken and guinea fowel. Poultry Science 87:1841-1848 .

- Ku YH, Chuang YC and Yu WL. (2008): Clinical spectrum and molecular characteristics of Klebsiella pneumoniae causing community- acquired extrahepatic abscess. J Microbiol Immunol Infect. 41: 311-317.

- Liu, Y.; Liu, C.; Zheng, W.; Zhang, X.; Yu, J.; Gao, Q.; Hou, Y. and Huang, $X$. (2008): PCR detection of Klebsiella pneumoniae in infant formula based on $16 \mathrm{~S}-23 \mathrm{~S}$ internal transcribed spacer. Inter. J. Food Microbiol., 125: 230-235.

- Mahalingam, P.; Masillamony, P. R.; Palanismuni, K.S. and Venugopalan, V. T. (1988): Virulence attributes of E. Coli wdKlebsiella isolates from hatcheries. Ind. Vet J., 65 (4): 283- 287.

- Nawaz, I., Munir, R., Farooq, U., Kausar, R. and Khanum, A. (2006): Whole cell protein profiling of Pasteurella multocida field isolates in Pakistan. Pakistan Veterinary Journal, 26(4): 157- 160. 
- Petri and Watson (1999): Statistics for Veterinary and Animal Science, $1^{\text {st }}$ Ed., U.S.A. Prevalence of antibodies against ORT in broilers and breeders in Southeren Brazil. Avian Diseases, 47:731-737.

- Plesser, O. ;Even-Shoshan, A. and Bendheim, U.(1975): The isolation of Klebsiella Pneumoniae from poultry and hatcheries. Refuah Vet., 32 (3):99-105.

- Rennie, R. P.;Anderson , C.M.;Weinsley , B .C.;Albritton ,W.I.and mahony, D.E.(1990): Klebsiella Pneumoniae gastroenteritis masked by clostridium perfringens. J.Cline. Microbio., 28 (2):216-219.

- Sandra, O.; Jesas and J,H.,Duarte carreia (1998): Potential pathogens recovered from upper respiratory tract of Psittacine birds. Department of morphology antMinical Facu. Of Vet. Rua Gomes. Freler 1199 Lisboa Codex. Portugal.

- Sarakby, T.M.B. (1979): Studies on the epidemiology of K. infection in poultry, M.V. Sc. Thesis Fac. Vet. Med. Cairo Unv.

- Sekariah, P. C. and Seth, R. N. (1957): Studies on Klebsiella pneumoniae infection in chicks Ind. Vet, J., 34, 315-320.

- Shivaprasad, H.L. (1998): An overview of anatomy, Physiology and Pathology of urinary system in birds, AV proceedings, $P P$.

- Sundaresan, N.R.; Sukumar, K.; Rajukumar, K.; Nagarajan, K.; Jaganathan, S. and Dorairajan, N. (2007): Antimicrobial susceptility of bacterial isolates from sheep different experimental patterns and ELISA. J. Egypt. Vet. Med. Assos. 62:57-71. 
- Tatum, F. M., Tabatabai, L. B. and Briggs, R. E. (2012): Cross-protection against fowl cholera disease with the use of recombinant Pasteurella multocida FHAB2 peptides Vaccine. Avian Dis. 56 (3): 589-91.

- Ullah, F Malik SA and Ahmed J (2009): Antimicrobial susceptibility pattern and ESBL prevalence in Klebsiella pneumoniae from urinary tract infections in the North-West of Pakistan. Afr. J. Microbiol. Res. 3:676-680.

- Van den Bogaard AE, Stobberingh EE (2000): Epidemiology of resistance to antibiotics. Links between animals and humans. Int $\mathbf{J}$ Antimicrob Agents. 14: 327-35.

- Wilkie, I. W., Grimes, S. E., Boyle, D. and Frost, A. J. (2000): The virulence and protective efficacy for chickens of Pasteurella multocida administered by different routes. Vet. Microbiol. 72 (1-2):57-68.

- Yu VL, Hansen DS, Ko WC, Sagnimeni A, Klugman KP, von Gottberg A, (2007): Virulence characteristics of Klebsiella and clinical manifestations of $K$. pneumoniae blood stream infections. Emerg Infect Dis. 13:986-93.

$$
\text { عدوى الكلبسيلا نيمونى فى دجاج التسمين }
$$

د./ مشيرة عباس محمد العباسى(1) ، د./ فارس فرج الخياط (1) ، د./ هانى(3) ، ط.ب/ مروه الطنطاوى(2)

$$
\begin{aligned}
& \text { (1) قسم أمراض الدواجن - كلية الطب البيطرى - جامعة كفر الشيخ. } \\
& \text { (2) قسم الباثولوجيا- كلية الطب البيطرى - جامعة كفر الثيخ. } \\
& \text { (3) - الددن الجامعية- جامعة طنطا. }
\end{aligned}
$$


استهدفت الدراسة مغرفة وبائية المرض وطرق العلاج المناسب لعدوى الكيبسيلا نيمونى كمسبب

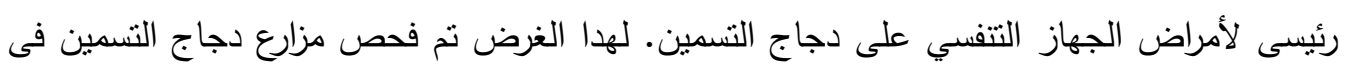
أماكن مختلفة فى محافظة الغربية فى الفترة من 2014-2017م.

تم الفحص البكتيريولوجى لعينات من الرئتين والقصبة الهوائية والكبد والأمعاء مجمعة من 20 مزرعة تسمين مصابة عند عمر 3-40 يوم كان تعانى من ضعف وصعوبة في التتفس وإفراز سائل مخاطي والتهاب في الغشاء الدخاطي والتهاب في الدويصلات الهوائية ونقص في إنتاج البيض وحدوث لهن نافق فى بعض الأحيان. ونفوق وأسفرت الصفة التشريحية عن وجود التهابات رئوية وتضخم فى الكبد

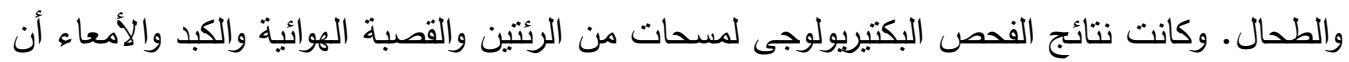
الميكروبات المعزولة كانت سالبة الجرام غير متحركة عصوية الثكل لها خاصية تجمع الصبغة عند طرفى الميكروب. - مبروباس

أسفرت النتائج عن عزل عدد 10عنرات من الكيبسيلا نيمونى بنسبة 6.6\% . تم عمل العدوى الاصطناعية لمعزولات الكيبسلا وتم نسجيل الأعراض الإكلينيكية والصفة التتريحية ونسبة النفوق وإعادة عزل الميكروب المحقون. أوضحت النتائج أن العترات المعزولة كانت شديدة الحساسية لكل من لكن (الجنتاميبسين، الأميكاسين سلفاميزاكزول)، ومتوسط الحساسية السييروفلوكساسين والكلوراميفيكول وقليل الحساسية لللنيوميسين ،نورفلوكساسين و الأوكسى تتراسيكلين ولكنه مقاوم اموكسيسيلين ، سيفالوسين النيوميسين وسيفوتكسيم.

حينما تم علاج الدجاج الدعدي اصطناعيا بحقن جنتاميسين والامكين لددة ثلاث أيام منتالية وإعطاء سلفاميزاكزول فى ماء الثرب فى نفس الوقت. لوحظ اختفاء الأعراض الإكلينيكية والصفة

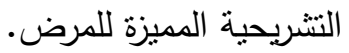

